\title{
Growth and Hematological changes of commercial birds fed on blood meal supplement with water
}

\author{
M. Shahidullah, M. Uddin and M.A. Habib ${ }^{1}$ \\ Department of Physiology and ${ }^{1}$ Department of Animal Breeding \& Genetics, Bangladesh Agricultural \\ University, Mymensingh-2202, Bangladesh
}

\begin{abstract}
The experiment was conducted to investigate the effects of blood meal supplement on growth performance and hematological parameters changes in broiler chicks. The experiment was carried out with 40 selected homogenous sex and weight broiler chicks having 10 for each group. The lay out of the study was conducted with control group A, fed only with standard commercial broiler ration and other groups viz. B, C, and D were fed with standard commercial ration in addition to $2.5 \%, 5.0 \%$, and $7.5 \%$ blood meal supplement with water respectively for 15 days $\left(21^{\text {st }}\right.$ to $35^{\text {th }}$ days of age). The activities of broiler chicks, growth performance, weight loss or gain and any kind of abnormalities were closely observed in every day and the body weight was recorded at 7 days interval. During feeding of blood meal all treated groups were found increased body weight at different level. The blood meal supplied to the broiler chicks increased the growth performance that was directly proportional to the rate of blood meal supplement with water, because the ration was fixed for every group. In hematological observations, TEC, $\mathrm{Hb}$ concentration and PCV were decreased but rapid decreasing occurs in group (B) that was statistically significant $(P<0.05)$. In this experiment during feeding of blood meal no clinical symptoms were found markedly. But slight symptoms occur when fed $7.5 \%$ blood meal. The data were analyzed by least significance difference (LSD) with a compute program SPSS-11.50 (Statistical packages for social sciences).
\end{abstract}

Keywords: Blood meal, Hematological parameters, Growth performance

\section{Introduction}

High cost of feeds is one of the major problems of commercial poultry production in Bangladesh. Its cost usually ranged between $65-75 \%$ of the total production cost (Haq and Akhtar, 2004 and Bhuiyan, 1998). This problem has resulted to reduce the rate of expansion of the poultry industry and has added to the low level of animal protein consumption and ultimately malnutrition to its people. A prospective way of increasing the supply of poultry products at cheaper prices is by reducing the cost of production through the use of cheaper, locally available sources of animal protein such as blood meal in place of costly fish meal and imported soybean meal, meat and bone meal, protein concentrate etc. Blood meal is a dark chocolate-coloured powder with characteristics smell contains high percentage (above 80\%) of crude protein (Sanger, 1981) and certain minerals particularly iron and copper. It is one of the richest sources of lysine, a rich source of arginine, methionine, cystine, leucine but is very poor in isoleucine and contain less glycine than either fish meal or bone meal (NRC, 1994). When we compare blood meal with vegetable protein supplements for poultry it is quite high in biological value. Generally, vegetable protein supplements are deficient in two of the essential amino acids which are lysine and methionine, but blood meal is rich in both of these amino acids (McDonald et al., 1992). Blood meal is obtained from slaughter house. In Bangladesh there are large numbers of animals that are being slaughtered every day and the blood from the slaughtered animals is drained off. The proper utilization of this product from the slaughter house has been limited due to lack of scientific knowledge regarding the processing. It is available every where in Bangladesh and we can easily collect, processed and store it. Blood meal is obtained when whole blood is cooked dried and ground to meal form. There is some evidence showing that 1 to $4 \%$ blood meal can be incorporated in the 
poultry diet with better growth performance (Petkov et al., 1980, Nuarautelli et al., 1987and Ikram et al., 1989). This is in contrast to the reports of others who have shown that the higher level of blood meal significantly improved the growth of chickens (Toor and Fahimullah, 1972, Hasan et al., 1974, Onwudike, 1981).Very little information is available of blood meal use in broiler diet. The present study was designed to assess the effects of using blood meal in the broiler diet on growth and changes of hematological values.

\section{Materials and Methods}

The experimental Farm (A private farm named, ARDF) was cleaned and washed using clean tap water and disinfected with strong disinfectant like losan ${ }^{R}$ and Virkon- $S^{R}$. Then the farm was kept empty for two days before placing the experimental birds. All necessary equipment was set properly to care the broiler chicks successfully. Proper hygienic and sanitary measures were also adopted during the experimental period.

A total of 40 Day old "Hubbard classic" broiler chicks were purchased from Pacific Hatchery, Valuka, Mymensingh. The chicks were brought to the ARDF for commercial rearing in a well ventilated paper cartons. The birds were reared throughout the entire period of study in proper atmosphere and hygienic condition providing sufficient brooder space and temperature, litter material and depth, floor space, feeder, drinker, lighting etc. according to the age of birds.

Fresh, clean and cool drinking water was made available. Standard commercial broiler ration (crumble and pelleted) formulated by Nourish Poultry Feed Ltd., Dhaka was used. The broiler chicks were fed with broiler starter for 1 to 14 days, broiler grower for 15-28 days and broiler finisher for 29-35 days of age. Birds were provided adlibitum feeds during the rearing period.

In order to prevent stress, shock, deficiencies and bacterial diseases some medicinal items were used with fresh and clean water as per scheduled followed by ARDF. To protect birds against viral diseases specially like New Castle disease (ND) and Infectious bursal disease (IBD)/ Gumboro Disease, all birds were also vaccinated as per scheduled followed by ARDF.

Processed Blood meal which contains $98 \%$ crude protein and $2 \%$ minerals was collected from the Miner feed Mills Kanhor Bazaar, Mymensingh.

When the broiler chicks were acquainted with the prevailing environment, prescribed feeding system and completed the scheduled vaccination program after 21 days old a total of 40 homogenous weight male selected birds with an average body weight of 1006 gms were divided into four equal groups $(n=10)$ as $A, B, C$ and $D$ and caged with an area of $3.0 \times 2.5 \mathrm{ft}$ per group. Initial body weight of each bird was recorded. One, out of four experimental groups was considered as control (Group-A) fed only with commercial ration and other groups (Group-B, C \& D) were fed with commercial ration in addition to blood meal supplement with water at the rate of $2.5 \%, 5.0 \%$ and $7.5 \%(0.25 \mathrm{gm} /$ litre, $0.50 \mathrm{gm} /$ litre and $0.75 \mathrm{gm} /$ litre of water) respectively for 15 days ( $21^{\text {st }}$ to $35^{\text {th }}$ days) . It is mention that $5.0 \%$ dose of blood meal with water is commercially normal dose for broiler which represents group C.

The body weight of each bird was measured with the help of a sensitive balance started from day 21 (start of experiment) and sequentially after 7 days interval up to the end of the experiment to assess the growth performance of birds of different treated groups. 
Blood specimens were collected at the end of experiment for hematological studies. $2 \mathrm{ml}$ blood was collected from wing vein of every bird by puncturing with disposable syringe and kept in a sterile test tube containing anticoagulant ( $4 \%$ sodium citrate solution) at a ratio of 1:10. The hematological studies were performed within a day of blood collection. Hematological parameters were total erythrocyte count (TEC), hemoglobin ( $\mathrm{Hb})$ concentration, packed cell volume (PCV) and erythrocyte sedimentation rate (ESR). Hematological parameters were studied in the BAU Physiology laboratory, Department of physiology, Faculty of Veterinary Science.

Completely Randomized Block Design (RBD) was used to analyze data. Data collected on body weight gain at different ages and hematological values were statistically analyzed by least significance difference (LSD) test using computer programme named Statistical Packages for Social Science (SPSS-11.50).

\section{Results and Discussion}

Body weight at different treatment groups at different ages are presented in Table 1. On an average, the body weight was highest $(2025 \pm 29.81 \mathrm{gm})$ in group $C$ at 35 days of age. In group B and D the body weight were more or less similar i.e. $1985 \pm 37.12$ and $1955 \pm 35.90$ gm respectively. But the control group contains $1770 \pm 32.66 \mathrm{gm}$ body weight which is significantly indicated less growth than the treated groups.

On the other hand, the body weight was lowest $(1500 \pm 42.69 \mathrm{gm})$ in group $C$ at 28 days of age. In group $B$ and $D$ the body weight were more or less similar i.e. $1550 \pm 25.82$ and $1530 \pm 32.66 \mathrm{gm}$ respectively. But in control group contains $1450 \pm 27.69 \mathrm{gm}$ body weight which is significantly indicated less growth than the treated groups.

The growth performance was directly proportional to the blood meal supply in the diet. At 28 and 35 days of age the body weight differed significantly $(P<0.05)$ between control and treatment groups but did not differ among treatment groups. The body weight on $21^{\text {st }}$ day indicates initial body weight and obviously they are statistically insignificant.

Table1. Body weight (Mean \pm SE) of broiler at different ages at different treatment groups

\begin{tabular}{|l|c|c|c|c|}
\hline Treatment groups & No of birds & $21^{\text {st }}$ days (Start) & $28^{\text {th }}$ days & $35^{\text {th }}$ days (End) \\
\hline A (control) & 10 & $1020 \pm 6.18$ & $1450 \pm 27.69^{\mathrm{a}}$ & $1770 \pm 32.66^{\mathrm{a}}$ \\
\hline B $(2.5 \% \mathrm{BM})$ & 10 & $1030 \pm 21.34$ & $1550 \pm 25.82^{\mathrm{bc}}$ & $1985 \pm 37.12^{\mathrm{b}}$ \\
\hline C $(5.0 \% \mathrm{BM})$ & 10 & $1030 \pm 12.38$ & $1500 \pm 42.69^{\mathrm{ab}}$ & $2025 \pm 29.81^{\mathrm{b}}$ \\
\hline D $(7.5 \% \mathrm{BM})$ & 10 & $1000 \pm 12.91$ & $1530 \pm 32.66^{\mathrm{ac}}$ & $1955 \pm 35.90^{\mathrm{b}}$ \\
\hline
\end{tabular}

$\mathrm{BM}=$ Blood meal

${ }_{\text {abc }}$ mean values having uncommon superscripts in the same column differed significantly $(P<0.05)$

Squibb and Braham (1955) partially supported the results of this experiment. They found that blood meal to be a satisfactory source of lysine in all vegetable protein rations for baby chicks. The blood meal was most effective when supplied at 2 to 4 percent of the ration. A level of 8 percent resulted in either no supplementary effect or in a depression of growth.

Slinger et al. (1950) also supported the findings of this experiment. They stated that combination of blood meal and keratin meal did not promote better growth than the blood meal alone. He also observed that 3 percent blood meal plus crystalline lysine produced better growth in poultry. In this study no lysine supplementation was made that may be reason for lack of growth promotion on dietary blood meal in the current observation. 
A positive relationship exists between the doses of blood meal and average body weight gain up to a certain level of doses. The increase body weight gain might be due to the increase level of blood meal supply, because blood meal possesses higher \% of crude protein which leads to enhance body weight gain in broiler.

So, it might be assumed that after a certain dose of blood meal in broiler can decrease the capability of digestion and absorption and ultimately decrease the body weight gain. $5.0 \%$ blood meal supplement with water increase the growth rate rapidly than other groups. So $5 \%$ blood meal supplement was found to be better growth performance in this experiment. This result agreed with the experiment of others. (Squibb and Braham 1955 and Slinger et al.1950 ; Sanger, 1981 )

The hematological values of broiler birds fed with blood meal at different doses were estimated. The results of various blood parameters are given in Table 2. The blood parameters i.e. Total erythrocyte count (TEC), Erythrocyte sedimentation rate (ESR), Packed cell volume $(\mathrm{PCV})$, and Hemoglobin $(\mathrm{Hb})$ concentration were more or less similar within all treatment groups.

The hematological values differed significantly $(P<0.001)$ between control and treatment groups. In case of TEC, ESR and PCV the values differed significantly among the treatment groups. But in case of $\mathrm{Hb}$ the values did not differ significantly among the different treatment groups because the supplementation of bloodmeal may leads to increase the globin part of $\mathrm{Hb}$ but not Haem part of $\mathrm{Hb}$ due to lack of iron.

Table 2 Hematological parameters (Mean \pm SE) of broiler at different treatment groups

\begin{tabular}{|l|c|c|c|c|c|}
\hline Treatment group & No of birds & TEC (million/mm $\left.\mathrm{mm}^{3}\right)$ & $\begin{array}{c}\mathrm{Hb} \\
(\mathrm{g} / \mathrm{dl})\end{array}$ & $\begin{array}{c}\mathrm{ESR} \\
\left(\mathrm{mm} \mathrm{in} 1^{\text {st }} \mathrm{hr}\right)\end{array}$ & $\begin{array}{c}\text { PCV } \\
(\%)\end{array}$ \\
\hline A (Control) & 10 & $3.17 \pm 0.01^{\mathrm{a}}$ & $9.8 \pm 0.1^{\mathrm{a}}$ & $2.0 \pm 0.0^{\mathrm{a}}$ & $24.0 \pm 0.0^{\mathrm{a}}$ \\
\hline $\mathrm{B}(2.5 \% \mathrm{BM})$ & 10 & $2.67 \pm 0.01^{\mathrm{b}}$ & $8.2 \pm 0.1^{\mathrm{b}}$ & $4.0 \pm 0.21^{\mathrm{b}}$ & $19.0 \pm 0.21^{\mathrm{b}}$ \\
\hline $\mathrm{C}(5.0 \% \mathrm{BM})$ & 10 & $2.86 \pm 0.01^{\mathrm{c}}$ & $8.2 \pm 0.1^{\mathrm{b}}$ & $2.0 \pm 0.0^{\mathrm{a}}$ & $21.0 \pm 0.0^{\mathrm{c}}$ \\
\hline $\mathrm{D}(7.5 \% \mathrm{BM})$ & 10 & $2.71 \pm 0.01^{\mathrm{b}}$ & $8.4 \pm 0.1^{\mathrm{b}}$ & $4.0 \pm 0.0^{\mathrm{b}}$ & $19.0 \pm 0.0^{\mathrm{b}}$ \\
\hline
\end{tabular}

$\mathrm{BM}=$ Blood meal

${ }^{a b c}$ mean values having uncommon superscripts in the same column differed significantly $(P<0.05)$

TEC = Total erythrocyte count, $\mathrm{HB}=$ Hemoglobin, ESR = Erythrocyte sedimentation rate, $\mathrm{PVC}=$ Packed cell volume

The highest value of TEC found in group A (3.17 \pm 0.01 million $\left./ \mathrm{mm}^{3}\right)$ and lowest in group B $\left(2.67 \pm 0.01 \mathrm{million} / \mathrm{mm}^{3}\right)$. The values between treated groups and control group differed significantly $(P<0.001)$. The highest value of $\mathrm{Hb}$ content was recorded in group $\mathrm{A}(9.8 \pm 0.1$ $\mathrm{gm} / \mathrm{dl})$ and lowest in group B $(8.2 \pm 0.1 \mathrm{gm} / \mathrm{dl})$. The values between treated groups and control group differed significantly $(P<0.001)$. The highest values of ESR found in group $B$ and D ( $4 \pm 0.21 \mathrm{~mm}$ in first hour) and lowest in group $A$ and $C(2 \pm 0 \mathrm{~mm}$ in first hour). The values between treated groups, $B$ and $D$ and control group differed significantly $(P<0.001)$ but did not differed significantly in group $C$. The highest value of PCV found in group A (20 \pm $0.0 \%)$ and lowest in group B $(19 \pm 0.21 \%)$. The values between treated groups and control group differed significantly $(\mathrm{P}<0.001)$.

On the observation of blood profile studies after treatment of different doses of blood meal there were decrease of TEC, Hb concentration and PCV and increase of ESR content in the birds. Ahmed et al. (1994), Donkoh et al. (1999), Odunsi et al. (1999) reported that hematological parameters are unchanged in protein treatment. Decrease TEC, Hb, PCV and increase ESR values in this experiment contradict with their findings. 
There is also an evidence of little increase in total Erythrocyte count (TEC), Packed cell volume (PCV) and Hemoglobin $(\mathrm{Hb})$ concentration which indicate the good condition of broiler health (Elangovane et al., 2001). They stated that the ESR, PCV, TEC was comparable for all dietary protein groups. Decrease TEC, Hb and PCV values may be due to higher growth rate of birds compare to control group. Increase bloodmeal supply leads to increase growth rate of birds rapidly due to protein binding but the values of TEC, PCV, ESR and $\mathrm{Hb}$ may not increase rapidly as rapid growth.

Actually no clinical symptoms were manifested in all groups. But slightly marked in group D that might be due to excess dose of blood meal. The symptoms were slight dullness, depressed, and semisolid mucus to watery dyspanea, shaking of head, frequent defecation with watery and blackish feces because excess dose of blood meal may reduce the rate of digestibility.

Finally, it may be concluded that the blood meal can be used as a supplemental source of animal protein with drinking water for broiler, but it is better not to use as the sole source rather than tolerant doses. It may, however be suggested that $5 \%$ doses of blood meal with drinking water for broiler may be included for better utilization and performance.

\section{Acknowledgement}

The authors are highly grateful to the authority and personnel of the private farm named Agricultural Research and development Farm (ARDF), Sutiakhali, Mymensingh for their cordial co-operation to conduct the experiment successfully.

\section{References}

Ahmed, M.K., Barque, A.R., Nawaz, H. and Siddique, R.H. 1994. Effect of varying energy and protein levels on the hematology of Japanese quails. Pakistan Veterinary Journal. 14: 200-202.

Bhuiyan, M.Z. 1998. Complete replacement of fishmeal by full fat soybean and supplementation of Lysine and Methionine to broilers. M.S. Thesis, Department of Poultry Science, BAU, Mymensingh.

Donkoh, A., Atuahene, C.C., Anang, D.M. and Otori, S.K. 1999. Chemical composition of solar dried blood meal and its effect on performance of broiler chickens. Animal Feed Science and Technology. 81(3-4): 299-307.

Elangovan, A.V., Verma, S.V.S., Sastry, V.R.B. and Singh, S.D. 2001. Rapeseed meal as a protein supplement in diets for growing Japanese quit. Archiv for Geflugelkunde. 65(3): 114-117.

Haq, A. and M. Akhtar, 2004. Poultry Farming Higher Education Commission, Islamabad, Pakistan. 260: 221-231.

Hassan, O.E.M., A.M.S. Mukhtar and M.E.A. Nasir, 1974. The use of blood meal in tropical broiler diets. Trop. Anim. Health Prod., 6: 179-182.

Ikram, H., M.N. Ahmed and M.M. Ehtisham, 1989. Effect of different levels of blood meal on broiler performance. Pak. J. Vet. Res., 2: 51-54.

McDonald, P., Edwards and J.F.D. Greenhalgh, 1992. Animal Nutrition. $4^{\text {th }}$ ed. Published in the United States with John Wiley and Sons. Inc. NewYork, pp: 455-483.

NRC, 1994. Nutrient requirement for Poultry. $9^{\text {th }}$ Ed. National Academy Press. Washington DC, USA.

Nuarautelli, A., A. Anghinelli and A. Blanco, 1987. Use of spray dried blood meal in broiler diet. Medicinia Veterinaria, Universita di Parma, Italy, pp: 333-353.

Odunsi, A.A., Onifade, A.A. and Babatunde, G.M. 1999. Response of broiler chicks to virginimycin and dietary protein concentrations in the humid tropics. Archivosdezootunia. 48(183): 317-325.

Onwudike, O.C., 1981. Effect of various protein sources on egg production in a tropical environment. Trop. Anim. Prod., 6: 249-256. 
Petkov, S., O. Kacervsky, Z. Sova, I. Kalous, L. Slauk, F. Bouska, Z. Jedlicka, M. Stradel and L. Parizokova, 1980. Possible part or complete replacement of animal meals by spray dried blood from preserved or non preserved blood in feeds for broilers. Praze Fakulfa Agronomicka, 31: 33-34. Nutr. Abstr. Rev., 51:135.

Sanger, S.S. 1981. Low cost ration formulation in Poultry. Poultry Adviser. 15: 25-29.

Slinger, S.J., D.C. Hill, K.M. Gartley and H.D. Branion. 1950. Soyabean oil meal and sunflower seed oil meal in rations for abroad breasted bronze turkeys. Nutr. Abstr. and Rev. 19: 733.

Squibb, R.L. and J.E. Brahman. 1955. Blood meal as a lysine supplement to all vegetable protein rations for chicks. Poultry Sci. 34: 1050.

Toor, A.A. and Fahimullah, 1972. Effects of different levels of blood meal on the performance of broiler chick. M.Sc. Thesis, Deptt. Poultry Husbandry, Univ. Agri. Faisalabad. 